\title{
EU appoints Ebola coordinator
}

\author{
Rory Watson
}

\section{Brussels}

The European Union is stepping up its efforts to tackle the Ebola crisis in west Africa by appointing an overall coordinator, increasing funding, and deploying more medical and support staff to the region.

The issue was high on the agenda of the EU leaders' summit meeting in Brussels on 23 and 24 October. They agreed that, with the first confirmed cases of Ebola virus disease in Europe, protection of European countries and their citizens was "of the utmost importance." They pointed to the need for precautionary measures "to reduce risks of contagion, including coordinated preventive actions within the EU such as sharing of information and best practices, training of health professionals, and, where appropriate, entry screening."

To give greater visibility and coherence to the EU's input to the international campaign against the virus, the summit appointed Christos Stylianides, who begins his five year term as European humanitarian aid and crisis management commissioner on 1 November, as the EU's Ebola coordinator.

Speaking publicly for the first time in his new role on 27 October, Stylianides, a dental surgeon and Cypriot politician, admitted, "Let us be sincere. In the case of the Ebola disease, the international community - all of us - underestimated the danger and the extent of the threat." He confirmed that he would visit west Africa in the second week of November to express the EU's solidarity with the afflicted countries and "to better assess the needs and gaps in our efforts."

Part of those needs may be met by funding. By the end of last week funding from the EU and its member countries had reached over $€ 600 \mathrm{~m}$ ( $£ 470 \mathrm{~m} ; \$ 760 \mathrm{~m}$ ). A further $€ 200 \mathrm{~m}$ had been pledged by 27 October, and the aim is to raise the total to $€ 1 \mathrm{bn}$ in the coming weeks. Part will also come from what Stylianides termed "in-kind assistance."

The number of available beds in the region, 1000, would need to be increased to 5000 as soon as possible and would require 40000 health and support staff, said Stylianides. The EU, he confirmed, was now looking to mobilise volunteer medical personnel and, to reassure them, has already put in place an evacuation system for any international health workers who might need it.

The European Commission has created a taskforce within its emergency response coordination centre to act as an overall clearing house. It is also drawing on expertise from its various departments.

Commission health officials are involved in all aspects related to protecting the European public. Over $€ 24 \mathrm{~m}$ has been allocated to encourage research into the creation and production of a vaccine. Other officials are working on keeping air and sea transport links with west Africa open and on making sure that neighbouring countries are well prepared if the disease spreads.

Access all of The BMSS content on the ongoing Ebola outbreak at thebmj.com/ebola.

Cite this as: BMJ 2014;349:96497

๑ BMJ Publishing Group Ltd 2014 